\title{
Clinicopathology profile evaluated against several risk factors in breast cancer cases
}

Idral Darwis*, Muchlis Ramli*, Didid Tjindarbumi*, Esti Soetrisno\#,Gu nawan Tjahjadi\#, Endang Sri Roostini\#, Santoso Comain\#, Drupadi S Dillon"', Joedo Prihartono*, Setyawati Budiningsih§, Goi Sakamoto-, Yoshiyuki Ohno", Kenji Wakait

\begin{abstract}
Abstrak
Telah dilakukan penelitian dua ratus dua puluh enam kasus kanker payudara (KPD) yang berhubungan dengan aspek klinik dan pato/ogi serta faktor risiko yang berhubungan dengan terjadinya keganasan payudara. Distribusi terbanyak pada umur antara 35-55 tahun dengan frekuensi tertinggi antara umur 40-50 tahun. Tidak didapatkan perbedaan lokasi tumor pada payudara kanan atau kiri serta distribusi pre-menopause maupun post-menopause. Delapan puluh satu koma enam persen KPD ditemukan pada stadium lanjut (stadium IlfA: 17,7\%, JJJB: 56,2\% dan JV: 11,9\%), sedangkan stadium !: 1,3\% dan stadium fl: 11,9\%. Tujuh puluh Lima dari 226 kasus dilakukan tindakan pembedahan: 60\% mastektomi simpel, 26,7\% mastektomi radikal dan 1,3\%: breast cancer concerving treatment ( BCT). His- topatologi dari jaringan payudara dari 214 kasus didapatkan karsinoma invasif yang terdiri dari: 90,4\% karsinoma duktal invasif dan 9,6\% tipe khusus. Dilakukan analisa dari beberapa faktor risiko seperti status kawin, umur pada saat kawin pertama, umur menarche, status menopause, laktasi, riwayat keluarga KPD, penggunaan kontrasepsi dan konsumsi tinggi lemak. Hasil dari metode kasus kontrol menunjukkan bahwa faktor-faktor status menopause, laktasi dan konsumsi tinggi lemak meningkatkan risiko terjadinya $K P D$, dengan risiko relatif masing-masing: 1,51, 1,83 dan 2,61.
\end{abstract}

\section{Abstract}

The second batch case-control study on breast cancer has been conducted as a joint study between Indonesian and Japan. Two hundred and twenty six (226) cases of breast cancer was collected to assess the risk factors and evaluated for their clinical presentation of the disease. The age distribution in some high risk areas showed at age 35 to 55 years, with a single peak between 40 to 50 . There was no difference in number of cases in respect to tumor site and menopausal status. The majority of cases $81.6 \%$ were in advanced stage (I!JA: $17.7 \%$, JfIB: $56.2 \%$ and JV: $11.9 \%)$ while in contrast stage l and fl were very rare (1.3\% and $11.9 \%$ respectively). Only 75 cases were operable; simple mastectomy was the most frequent surgery carried out (60.0\%), followed by modified radical mastectomy (26.7\%), classical radical mastectomy (12\%) and breast conserving treatment (1.3\%). The specimens were reviewed using classification recommended by the Japanese Breast Cancer Society revealed invasive ductal carcinoma (90.4 o/o) and the special type (9.6 o/o). Several risk factors were analyzed for their influence to the development of breast cancer; namely: marital status, age at first marriage, menarche, menopausal status, lactation, family history of breast cancer; use of contraceptive and fat consumption. Among the characteristics studied, the following factors significantly increased the risk of breast cancer: menopausal status (RR=1.51; 95\% Cl: 1.10-2.09), non-lactating children (RR=l.83; 95\% CJ: 1.07-3.JI) and fat consumption ( $R R=2.61 ; 95 \% \mathrm{Cl}$ : 1.86-3.68), while the use of contraceptive showed protective effect. Thefindings will be discussed in its benefit relative to both the improvement of the treatment modality and the cancer control prog ram.

Keywords: Breast cancer, clinicopathological, case-control study, epidemiology

* Department of Surgery, Faculty of Medicine, University of Indonesia, Jakarta 10430, Jndonesia

\# Department of Pathology, Faculty of Medicine, University of Indonesia, Jakarta 10430, Indonesia

= Department of Nutrition, Faculty of Medicine, University of Indonesia, Jakarta 10430, Indonesia

Department of Community Medicine, Faculty of Medicine, University of Indonesia, Jakarta 10320, Indonesia

- Department of Pathology, Cancer Institute Hospital, Tokyo 170, Japan

t Department of Preventive Medicine, School of Medicine, Nagoya University. Nagoya 466, Japan

\section{INTRODUCTION}

Carcinoma of the breast continue to baffle the surgeons and the pathologists for the unpredictable biological behavior and many gap in the knowledge of the factors that either control or influence tumor genesis and growth. In Indonesia breast cancer ranked second most common malignant tumor of the females. Up to 678 cases of breast cancer were hospitalized in Dr. Cipto Mangunkusumo Hospital, Jakarta, during the 5 years period- 1986-1990. Data collected from Pathological Base Cancer Registry showed relative frequency $18.03 \%$ with Age Stand- 
ardize Cancer Ratio (ASCAR) 17.84\% in 1988 and 18.44\% (ASCAR 17.48\%) in 1989. ${ }^{1}$

More articles have been published on breast cancer.27 but accumulation of know ledge has not produce any commensurate degree of agreement among research worker and clinicians on epidemiological, etiological, pathological and treatment problem of breast cancer. Thomas Huxley wrote "A great tragedy of science the staying of a beautiful hypothesis by an ugly fact". Wider understanding of different modalities, natural history of the disease and host-tumor relationship are some of the encouraging factors toward better salvage of this disease. A team work is needed for the management of breast cancer without prejudice to the specialty.

This study was conducted to find out the clinicopathological findings and incidence of the disease in relation to other parameters along with the known etiological factors.

\section{MATERIAL AND METHODS}

Material s consisted of women who underwent treatment at the Division of Surgical Oncology, Department of Surgery - Dr. Cipto Mangunkusu mo Hospital, Jakarta, during the period of February 1992 to September 1995 and were diagnosed as having histologically confirmed breast carcinoma. The medical records comprising 226 cases, aged 29 to 74 years (median age 45 years), were reviewed. A detailed clinical history and clinical examination were taken. Clinical staging was done by criteria according to the International UICC TNM System for Malignant Tumors and the surgical specimens were reviewed using the classification recommended by the Japanese Breast Cancer Society (1984)9.

With the same cases (226) several potential factors for breast carcinoma, namely: marital status, age at first marriage, menarche, menopausal status, lactation, family history of breast cancer, use of contraceptive and fat consumption were recorded. A casecontrol study design with 1:2 ratio was applied in this assessment. Each risk factor was assessed through univariate analysis and was measured its estimated Relative Risk and 95\% Confidence Intervals.

\section{RESULTS}

\section{Age}

We found that significant increase of the proportion of breast cancer cases in women started and peaked at comparatively younger age as compared to women in the Western countries. Table 1 and Figure 1 shows the details of age incidence and the commonest incidence was in age groups 30-39, 40-49 and 50-59 (28.3\%, $30.1 \%$ and 28.8\%) respectively. The incidence sharply decrease with advancing age. The youngest case of breast cancer was 29 years old and the oldest 74 years.

Table 1. Distribu tion of 226 cases of breast cancer and 552 controls according to age of patients

\begin{tabular}{crrrr}
\hline Age & Cases & \multicolumn{1}{c}{$\%$} & Control & $\%$ \\
$25-29$ & 3 & 1.3 & 4 & 0.9 \\
$30-39$ & 64 & 28.3 & 136 & 30.1 \\
$40-49$ & 68 & 30.1 & 141 & 31.2 \\
$50-59$ & 65 & 28.8 & 115 & 25.4 \\
$60-69$ & 23 & 10.2 & 53 & I 1.7 \\
$\ldots . . .: 70$ & 3 & 1.3 & 3 & 0.7 \\
\hline Total & 226 & & 552 & \\
\hline
\end{tabular}

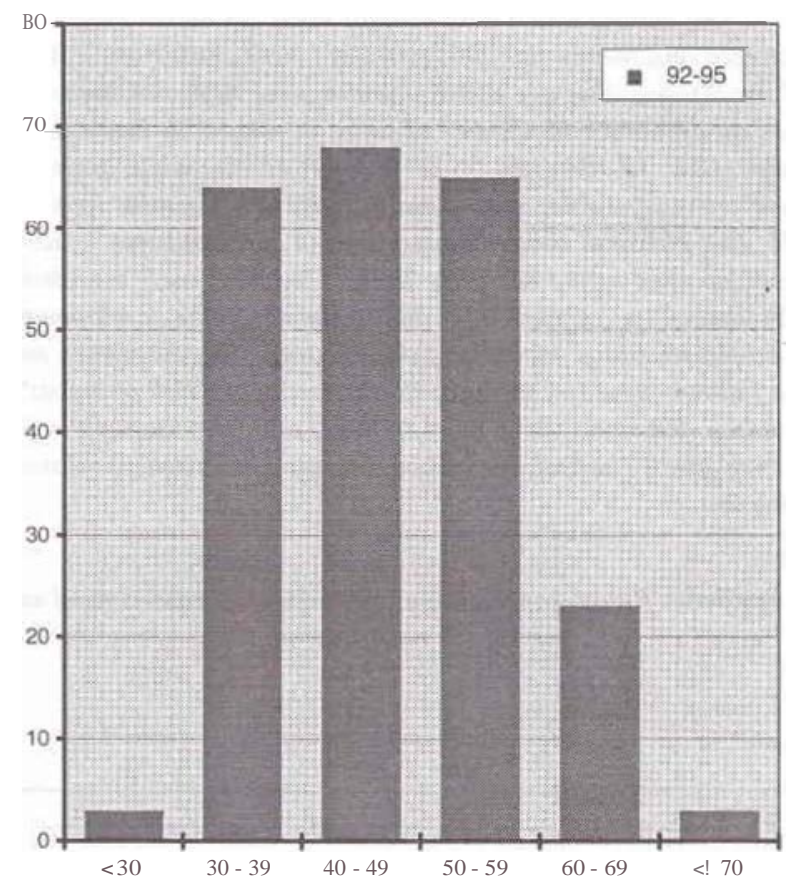

Figure L Age distribution of 226 cases of breast cancer (histogram)

\section{Menopausal status}

Correlation with hormonal status is shown in Figure 2. One hundred thirteen (50.22\%) cases were premenopausal and 112 (49.78\%) were post menopausal. 


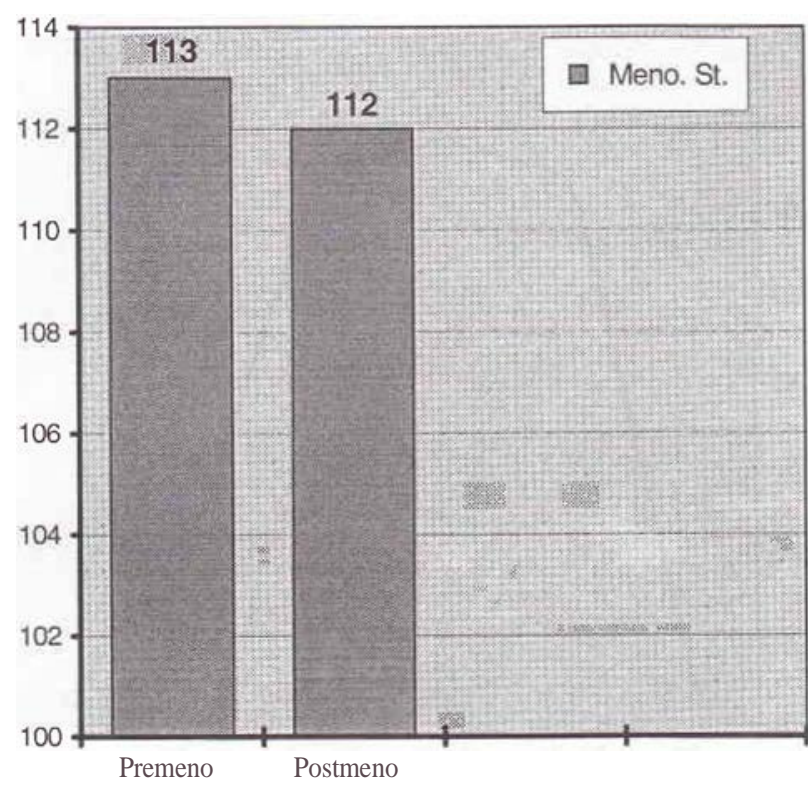

Figure 2. Distribution of 225 breast cancer by menopausal status

\section{Clinical features}

The right breast was in volved in $48.2 \%$, left breast in $48.7 \%$ and bil ateral tumor was present in 1.8\% (Table 2). Staging of the disease (Table 3) was done by the UICC TNM Classification of Malignant Tumors criteria; $1.3 \%$ were in stage I, I1.9\% in stage II, $17.7 \%$ in stage IIIA, $56.2 \%$ in stage IIIB and $11.9 \%$ in stage IV. The highest number of cases had advanced disease (Stage IIIB) and proposed treatment was palliation.

Table 2. Side in volvement of breast cancer cases

\begin{tabular}{lcc}
\hline Side affected & No. of cases & $\%$ \\
\hline Right & 109 & 48.2 \\
Left & 110 & 48.7 \\
Bilateral & 4 & 1.8 \\
\hline
\end{tabular}

Table 3. Distribution of breast cancer cases according to clinical staging $(n=226)$

\begin{tabular}{lrr}
\hline Stage & Cases & $\%$ \\
& 3 & 1.3 \\
II & 27 & 11.9 \\
JIIA & 40 & 17.7 \\
IJIB & 127 & 56.2 \\
IV & 27 & 11.9 \\
Unknown & 2 & 0.8 \\
Total & 226 & 100.0 \\
\hline
\end{tabular}

\section{Treatment}

The treatment modality in operable cases (33.2\%) in shown in Table 4. Radical mastectomy and modified rad ical mastectomy were adopted as initial treatment in the Department of Surgery for Stage I and Stage II which was done in 29 cases. Adjuvant radiation was performed if there was clinical evidence of regional metastasis. Stage IHA cases were treated by simple mastectomy (60\%).

Table 4. Type of operation performed in 75 cases

$\begin{array}{lcc}\text { Type of operation } & \text { No. of cases } & \% \\ \text { Radical mastectomy } & 9 & 12.0 \\ \text { Modified radical mastectomy } & 20 & 26.7 \\ \text { Simple mastectomy } & 45 & 60.0 \\ \text { Lumpectomy } & \text { I } & 1.3\end{array}$

\section{Histopathology}

Histology classification of Japanese Breast Cancer Society have been adopted to classify breast carcinoma (Table 5). Scirrhous adenocarcinoma was the commonest type of cancer.

Table 5. Histological pattern of breast cancer cases according to classification recommended by Japanese Breast Cancer Society (1984)

\begin{tabular}{|c|c|c|c|c|}
\hline Histological types & No. of cases & Right & Left & $\%$ \\
\hline \multicolumn{5}{|l|}{ Non-invasive carcinoma } \\
\hline \multicolumn{5}{|l|}{ Invasive carci noma } \\
\hline \multicolumn{5}{|l|}{ a. Invasi ve ductal carcinoma } \\
\hline al. Papillotubular & 15 & 7 & 8 & \\
\hline a2. Solid-tubular & 65 & 27 & 38 & \\
\hline a3. Scirrhous & 118 & 61 & 57 & \\
\hline \multicolumn{5}{|l|}{ b. Special types } \\
\hline b 1. Muci nous carcinoma & 5 & 4 & I & \\
\hline b2. Medullary carcinoma & 10 & 5 & 5 & \\
\hline $\begin{array}{l}\text { b3. Invasive lobular carcinoma } \\
\text { b4. Squamous cell carcinoma }\end{array}$ & $\mathrm{a}$ & 2 & 3 & \\
\hline \multirow[t]{2}{*}{ c. Unclassified and other } & 11 & & & \\
\hline & 225 & 106 & 113 & \\
\hline
\end{tabular}

Notes: four cases bilateral 
Table 6. Univariate logistic analysis of odds ratios (RR) and confidence interval (CI) for breast cancer risk factors

\begin{tabular}{|c|c|c|c|c|}
\hline Covariates & Cases & Controls & $\mathrm{RR}$ & $95 \% \mathrm{Cl}$ \\
\hline \multicolumn{5}{|l|}{ Menarche } \\
\hline$<15$ & 109 & 232 & 1.00 & \multirow{2}{*}{$\begin{array}{l}\text { Reference } \\
(0.82-1.56)\end{array}$} \\
\hline 15 & 116 & 218 & 1.13 & \\
\hline \multicolumn{5}{|c|}{ Menopausal status } \\
\hline No & 112 & 270 & 1.00 & \multirow{2}{*}{$\begin{array}{c}\text { Reference } \\
\text { ( I.I 0-2.09)* }\end{array}$} \\
\hline Yes & 113 & 180 & 1.51 & \\
\hline \multicolumn{5}{|c|}{ Marital status } \\
\hline Married & 177 & 354 & 1.00 & \multirow{3}{*}{$\begin{array}{c}\text { Reference } \\
(0.62-1.40)\end{array}$} \\
\hline Widowed & 45 & 97 & 0.4 & \\
\hline Unmarried & 2 & 0 & & \\
\hline \multicolumn{5}{|c|}{ Use of contraception } \\
\hline No & 170 & 311 & 1.00 & \multirow{2}{*}{$\begin{array}{c}\text { Reference } \\
(0.46-0.98)^{*}\end{array}$} \\
\hline Yes & 49 & 133 & 0.67 & \\
\hline \multicolumn{5}{|l|}{ Lactation } \\
\hline Yes & 194 & 418 & 1.00 & \multirow{2}{*}{$\begin{array}{c}\text { Reference } \\
(1.07-3.11)^{*}\end{array}$} \\
\hline No & 28 & 33 & 1.83 & \\
\hline \multicolumn{5}{|l|}{ Family BC } \\
\hline No & 213 & 422 & 1.00 & \multirow{2}{*}{$\begin{array}{l}\text { Reference } \\
(0.22-1.35)\end{array}$} \\
\hline Yes & 6 & 22 & 0.50 & \\
\hline \multicolumn{5}{|c|}{ Age of marriage } \\
\hline 20 yrs & 98 & 222 & 1.00 & \multirow{2}{*}{$\begin{array}{c}\text { Reference } \\
(0.59-1.12)\end{array}$} \\
\hline$<20$ yrs & 121 & 222 & 0.81 & \\
\hline \multicolumn{5}{|c|}{ Fat consumpt. } \\
\hline :.:; 26 & 65 & 232 & 1.00 & \multirow{2}{*}{$\begin{array}{c}\text { Reference } \\
(1.86-3.68)^{*}\end{array}$} \\
\hline$>26$ & 161 & 220 & 2.61 & \\
\hline \multicolumn{5}{|c|}{ Calories intake } \\
\hline s:; 1854 & 115 & 258 & 1.00 & \multirow{2}{*}{$\begin{array}{l}\text { Reference } \\
(0.93-1.77)\end{array}$} \\
\hline$>1854$ & 111 & 194 & 1.28 & \\
\hline
\end{tabular}

\section{DISCUSSION}

Although the risk of breast cancer increases with progressing age,2-4 a special age curve distribution has been observed. From 226 cases (Fig: 3), breast cancer incidence rises quickly between ages 30 and 35 , and levels on and off to a plateau between 35 and 55 , and after age 55 decline slowly. This is different from De Waard 's report (1964) of double peaks at 45 to 49 and 65 to 70 . Hen n ingsen (1975) reported only single peak between 50 and 60.4 Other dissimilar figu re was incidence of breast cancer in young women, defined as 40 years or less. Commission on Cancer of the American College of Surgeons reported 23.974 cases diagnosed in 1990: $0.8 \%$ were 30 years of age or less and $6.6 \%$ were in the age range of 31 to 40 . In the present study $1.3 \%$ were less 30 years and $28.3 \%$ in the age range of 30 to 39 years.s

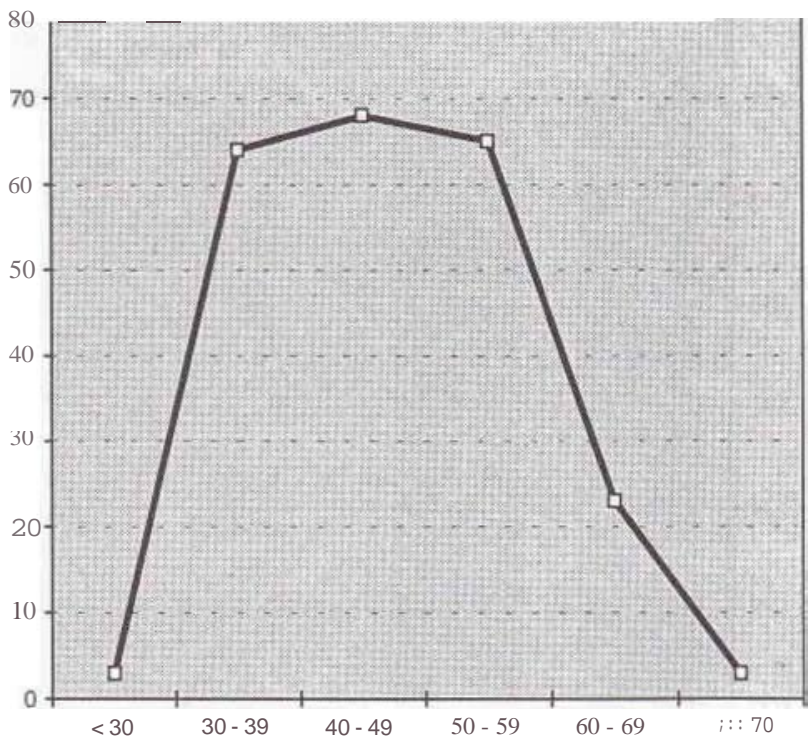

Figure 3. Ag e distribution curve for 226 breast cancer patients

The majority (85.8\%) of 226 breast cancer were in advanced stage ( IIIA, IIIB and IV) and $13.2 \%$ were in early stage. The present study were similar with previous data but different from breast cancer in Japan, 8-9 which the majority were in early stage. Only on 75 cases performed surgery and Simple mastectomy (60\%) was mostly chosen proced ure due to high portion of advanced stage (IIIA). Surgical modality in early cases were radical mastectomy (12\%) and modified radical mastectomy (26.7\%).

Ductal (scirrhous), solid-tubular, papillotubular, medullary, muci nous and invasive lobular carcinoma were diagnosed in 52.44\%, 28.89\%, 6.6\%, 4.4\%, $2.2 \%$ and $2.2 \%$ of cases, respectively. Consideration of the histological parameter, such as degree of tubular, gland formation, size of cells and nuclei ( nuclear pleomorphism), degree of hyperch romatine and number of mitoses was also evaluated for prognostic evaluation. Sub type of invasive ductal carcinoma reflect the degree of differentiation such as well differentiated, moderate and poor differentiated in an order of papillotubular carcinoma, solidtubular carcinoma and scirrhous carcinoma. Depending on a grading system considering the above mentioned parameters, two third of the cases were grade III and only small portion grade I. The prognosis is usually favorable when tubular gland formation and stromal elastosis exist and when tumor mitosis and fibrosis are minimal (Wallgren et al, 1976). 
Despite of clinical staging, histological type and grade of tumor had a role to predict prognosis of breast cancer.

This case control study has been conducted to confirm causal relationship of nine important determinant factors for the development breast cancer among Indonesian women (Table 6). Unlike women in the developed countries, the Indonesian women differ in many aspects such as familial, non familial (environments) and socio-economically. Nine determinant factors have been assessed using univariate analysis (Table 6), and three of them showed significant associations with the development of breast cancer, namely: menopausal status (RR=1.51; 95\% CI: 1.10 2.09), lactation (RR=l.83; 95\% CI: 1.07-3.11) and fat consumption (RR=2.61; 95\% CI: 1.86-3.68). Menarche and the use of contraceptive which are related to endocrine factors had not been found to be significant factor in this study. The earlier the age of menarche, with its associated earlier onset of "regular" menstrual cycles, the higher risk of breast cancerlD. The findings were not consistent with the notion that early menarche had been demonstrated as a risk factor in many studies. It is known that the interval from the menarche up to the establishment of regular menstrual cycle might be a better estimate for determinating the risk for breast cancer rather than the age of menarche. Women with early menarche (age 12 or younger) and rapid establishment of regular cycles had an almost fourfold increased risk of breast cancer when compared with women with late menarche (age 13 or older) and long duration of irregular cycles.11-12

The use of contraceptive showed protective effect in this study, which was different from the results of the first batch of study. The discrepancy might be due to small samples. Such unclear findings were also reported elsewhere, thus, further study is necessary to clarify the effect.

\section{Acknowledgments}

The authors are grateful to the nurses, Ms. Emi and Ms. Ros and for Public Health Nurses, Ms. July and Ms. Erlaini for excellent care and collection of data of breast cancer cases and controls. We are also indebted to the laboratory technician for excellent work on the surgicopathological specimens.
This work was supported by the Ministry of Education, Science, Sports and Culture of Japanese Government, Grants No. 01042007, 04042013 and 06042006; and was partly supported by the Indonesian Cancer Foundation. This collaborative study was a part of Special Cancer Research Project in Monbusho International Scientific Research Program, with the approval of the Dean, Faculty of Medicine University of Indonesia, No. 4383/PT02.H4.FK/E/ 88.

\section{REFERENCES}

1. Cornain S, Mangunkusumo R, Nasar IM, Prihartono J. Ten Most Frequent Cancers in Indonesia: Pathology based Cancer Registry Data of 1988-1992. In: Cancer Registry in Indonesia. National Cancer Register Center, Jakarta Coordinating Board, 1997.

2. Vorherr H. Breast Cancer - Epidemiology, Endocrinology, Biochemistry and Pathobiology, Urban \& Schwarzenberg, Inc., Baltimore - Munich, 1980: 25-36.

3. Vaidya MP, Shukla HS, A Textbook of Breast Cancer, New Delhi: Vikas Publishing House PVT LTD, 1983:124-30

4. Winchester DP. Breast Cancer in Young Women ., The Surgical Clinic of North America,1996; 76-2: 279-87

5. Boyd NF. Epidemiology of cancer. In: Tannock IF, Hill RP, editors. The Basic Science of Oncology, 2nd ed. Canada: Mc. Graw-Hill, Inc. 1992: 7-21.

6. Donn AS, Muir CS. Breast cancer: Epidemiology and risk factors. In: Khogali M, Omar YT, Gjorgov A, Ismail AS, editors. Cancer Prevention in Developi ng Countries. Oxford, Pergamon Press, 1986: 155-66.

7. . Kelsey JL, Horn-Ross PL. Breast cancer: Magnitude of the problem and descriptive. Epidemiol Reviews 1993; 15: 717.

8. TNM Atlas: Illustrated Guide to the TNM / P.TNM Classification of Malignant Tumours, 3n1 ed. Berlin: UICC Springer Verlag, 1990: 173-83.

9. . Japanese Breast Cancer Society, The General Rules for Clini- cal and Pathological Recording of Breast Cancer, Jpn I Surg 1989; 19: 612-32.

10. Apter D, Vihko R. Early menarche, a risk factor for breast cancer, indicates early onset of ovulatory cycles. J. Clin Endocrinol Metab 1983; 57: 82.

11. Henderson BE, HS Fergelson. In: Text Book of Breast Cancer-Clinical Guide to Therapy, United Kingdom Biddies Ltd, 1998: 1-16.

12. Henderson BE, Ross RK, Judd HL, et al. Do regular ovulatory cycles increase breast cancer risk? Cancer 1985; $56: 1206$.

13. N, Triaspolitica. "Kanker Payudara: Informasi, Penyebab, Gejala, Stadium Dan Pengobatan." Mau Nanya Dong Dok. N.p, 28 June 2017. Web. 30 June 2017.

$<$ https://nanyadongdok.blogspot.com/2017/06/kanker-payudarainformasi-penyebab.html>. 